\title{
Correlation of preoperative HRCT findings with surgical findings in Unsafe CSOM
}

\author{
Ginni Datta, C.Mohan, Monika Mahajan, Vandana Mendiratta. \\ Assistant professor, Dept of ENT, MMIMSR,Mullana,Ambala \\ Professor, Dept of ENT, Rohail Khand Medical College,Bareily \\ ENT Consultant, Civil Hospital, Ambala City \\ PG Student, Dept of ENT, MMIMSR,Mullana,Ambala
}

\section{Introduction:}

Chronic suppurative otitis media (CSOM) has been an important cause of middle ear disease since prehistoric times[1].Despite the valuable contribution of antibiotics, (CSOM) remains a common disease and its complications challenge both otologists and radiologists[2,3]. Radiological evaluation of the temporal bone is difficult owing to complicated anatomical structure of the middle ear and inner ear. A major advance in imaging of the ear structures has occurred with the development of HIGH RESOLUTION COMPUTED TOMOGRAPHY (HRCT) [4, 5].Thin section HRCT with modern equipment allows by means of special algorithms, imaging of osseous structures up to a spatial resolution of 0.45 to $0.65 \mathrm{~mm}$.HRCT has the advantage of excellent topographic visualization devoid of artifacts from superimposition of structures. Because the various components of the temporal bone are often seen in only one projection it is necessary to obtain scans in both planes of view axial and coronal. One set of conditions in which the indication of preoperative scanning is quite clear is when there are CNS Complications of CSOM.Other reasonable uses of CT scanning include preoperative facial paralysis, vertigo with positive fistula test and when revision mastoidectomy is contemplated in the absence of details of the previous procedure. Its ability to determine the extent of soft tissue involvement of the antrum ,middle ear and especially the posterior tympanic spaces may assist the surgeon in deciding between a canal wall up Vs an open procedure.[6] Doubts about sensitivity and specificity, in detecting the extent of underlying pathology and in predicting asymptomatic complications ,prevent widespread adoption.(7)Routine CT is not advocated for cholesteatoma diagnosis but may be important in complicated disease(revision cases, intact tympanic membrane, history does not correlate well with physical examination)[8].

\section{AIMS AND OBJECTIVES:}

1. To evaluate the role of HRCT in the diagnosis of unsafe CSOM.

2. To compare the preoperative HRCT findings with intr-operative findings in patients with unsafe CSOM.

\section{Material And Methods:}

This prospective study was conducted in the department of otorhinolaryngology and radio-diagnosis at IGMC, Shimla. 25 patients were selected whose clinical diagnosis was CSOM Attico-antral type.

\section{The criteria for selection of cases:}

Patients having attico-antral CSOM (unilateral or bilateral) disease

The criteria for exclusion of cases:

1. Suspicion of ear pathology to be malignant

2. Congenital ear disease

3. Clinically safe CSOM

4. Patients unfit for surgery or anesthesia

5. Old operated ear cases

6. Patient age less than 10 years

7. Osteoarthritis of the cervical spine.

All cases were clinically examined; pure tone audiometry was done, and duly investigated for surgery. HRCT was performed on all cases $1 \mathrm{~mm}$ sections in both axial and coronal planes were taken and findings recorded and tabulated. All patients underwent surgery and intraoperative findings were noted .Finally a comparison was done between HRCT and intraoperative findings.

\section{OBSERVATIONS} present study.

A total number of 25 cases of unsafe type of chronic suppurative otitis media were selected for the 


\section{AGE DISTRIBUTION:}

The patients were in the age group varying from second decade to fifth decade. Maximum number of patients belonged to the age group of 21-30 years. Mean age of the patients included in the present study was 26.76.)( Table 1)

TABLE1. AGE DISTRIBUTION

\begin{tabular}{|l|c|c|}
\hline Age Group(in years) & No. of cases & \%age \\
\hline $11-20$ & 6 & $24 \%$ \\
\hline $21-30$ & 13 & $52 \%$ \\
\hline $31-40$ & 5 & $20 \%$ \\
\hline
\end{tabular}

SEX DISTRIBUTION:

Female to male ratio in the present study was 1.27:1 .Out of a total number of 25 cases, 11(44\%) were found males and $14(56 \%)$ were females. (Table 2 )

Table2. SEX DISTRIBUTION

\begin{tabular}{|l|c|c|}
\hline Sex & No. of cases & \%age \\
\hline Males & 11 & $44 \%$ \\
\hline Females & 14 & $56 \%$ \\
\hline
\end{tabular}

DURATION OF SYMPTOMS:The duration of complaints in 20 cases (80\%) was more than 10 years and in 5 cases $(20 \%)$ less than 5 years. (Table 3 )

Table3. DURATION OF SYMPTOMS

\begin{tabular}{|l|c|c|c|}
\hline Symptoms & $1-5$ yrs & 6-10yrs & $>10$ yrs \\
\hline Otorrhoea & 5 & 0 & 20 \\
\hline Deafness & 5 & 0 & 20 \\
\hline
\end{tabular}

\section{COMPARISON BETWEEN COMPUTED TOMOGRAPHY AND PEROPERATIVE FINDINGS}

(A) DURAL AND SINUS PLATE

Dural plate erosion was seen in $4(16 \%)$ cases on CT, but preoperatively erosion was found in only $2(8 \%)$ cases. Intact dural plate was seen in $21(84 \%)$ cases on CT but intact dural plate was present in $23(92 \%)$ cases preoperatively. Sinus plate erosion was seen in $3(12 \%)$ cases and intact sinus plate was seen in $22(88 \%)$ cases, the same findings were confirmed preoperatively. (Table 4)

TABLE4. DURAL AND SINUS PLATE

\begin{tabular}{|l|c|c|c|c|}
\hline \multirow{2}{*}{} & \multicolumn{2}{|c|}{ CT findings } & \multicolumn{2}{c|}{ Operative findings } \\
\cline { 2 - 5 } & No. of Cases & \% age & 23 & \%age \\
\hline Dural plate Intact & 21 & $84 \%$ & 2 & $92 \%$ \\
\hline Eroded & 4 & $16 \%$ & 22 & $88 \%$ \\
\hline Sinus plate Intact & 22 & $88 \%$ & 3 & $12 \%$ \\
\hline Eroded & 3 & $12 \%$ & & 8 \\
\hline
\end{tabular}

(B) PNEUMATization OF MASTOID:

Mastoids were observed in all cases. In 24 (96\%) cases they were sclerotic; in the remaining one (4\%) case they were pneumatic. Same findings were true on both CT and operatively. (Table 5)

TABLE5. PNEUMATIZATION OF MASTOID

\begin{tabular}{|l|c|c|c|c|}
\hline \multirow{2}{*}{} & \multicolumn{2}{|c|}{ CT findings } & \multicolumn{2}{c|}{ Operative findings } \\
\cline { 2 - 5 } & No. of Cases & \% age & No. of cases & \% age \\
\hline Sclerotic & 24 & 96 & 24 & 96 \\
\hline Pneumatic & 1 & 4 & 1 & 4 \\
\hline
\end{tabular}

\section{(C) [I] PRE-OPERATIVE C.T.SCAN FINDINGS: [I] SOFT TISSUE MASS}

On comparing CT with preoperative findings, soft tissue masses were found in all 25 cases. Out of 18 $(72 \%)$ cases found to have cholesteatoma $15(60 \%)$ cases were associated with bone erosion and one $(4 \%)$ case with bone erosion was found to have granulation tissue only. (Table 6) 
TABLE6. SOFT TISSUE MASS

\begin{tabular}{|l|c|c|}
\hline Operative findings & No. of cases & \%age \\
\hline Soft tissue mass & 25 & $100 \%$ \\
\hline Cholesteatoma & 5 & $20 \%$ \\
\hline Granulation & 7 & $28 \%$ \\
\hline Both & 13 & $52 \%$ \\
\hline
\end{tabular}

\section{[II] DISTRIBUTION OF SOFT TISSUE MASS}

On CT the soft tissue in $19(76 \%)$ cases was present in both middle ear and mastoid, in 6(24\%) cases it was confined to middle ear only. Peroperatively soft tissue was present in middle ear and mastoid in $20(80 \%)$ cases and confined to middle ear in $5(20 \%)$ cases. (Table 7 )

TABLE7. DISTRIBUTION OF SOFT TISSUE MASS

\begin{tabular}{|l|c|c|c|c|}
\hline \multirow{2}{*}{ Site of soft tissue mass } & \multicolumn{2}{|c|}{ CT findings } & \multicolumn{2}{c|}{ Operative findings } \\
\cline { 2 - 5 } & $\begin{array}{c}\text { No. of } \\
\text { Cases }\end{array}$ & \% age & No. of cases & \%age \\
\hline Middle ear and mastoid & 17 & $68 \%$ & 18 & $72 \%$ \\
\hline Middle ear only & 6 & $24 \%$ & 5 & $20 \%$ \\
\hline Mastoid only & 0 & & 0 & $8 \%$ \\
\hline $\begin{array}{l}\text { EAC + middle ear+ } \\
\text { Mastoid }\end{array}$ & 2 & $8 \%$ & 2 & \\
\hline
\end{tabular}

(D) Comparison between preoperative CT scan and intra-operative findings:

[I] OSSICULAR STATUS:

Regarding ear ossicles malleus appeared to be intact in $6(24 \%)$ cases on CT, peroperatively it was found to be intact in $4(16 \%)$ cases in the remaining 2 cases it was partially eroded. On $\mathrm{Ct}$ malleus appeared eroded in $19(76 \%)$ cases and all these cases were confirmed preoperatively.

On CT incus appeared to be intact in $5(20 \%)$ cases, preoperatively it was found to be intact in $2(8 \%)$ cases, in the remaining 3(12\%) cases it was partially necrosed. On CT incus appeared to be eroded in $20(80 \%)$ cases and all these cases were confirmed preoperatively. On CT Stapes appeared to be intact in 11(44\%) cases, eroded in $4(16 \%)$ cases and not visualized in 10(40\%) cases, peroperatively it was eroded in 5 cases $(20 \%)$ and found to b intact in $20(80 \%)$ cases. Out of 10 cases not visualized on CT, all 10 were intact preoperatively. (Table 8).

TABLE8. OSSICULAR STATUS

\begin{tabular}{|cl|c|c|c|c|}
\hline \multirow{2}{*}{ Ossicles } & \multicolumn{2}{|c|}{ CT findings } & \multicolumn{2}{c|}{ Operative findings } \\
\cline { 2 - 6 } Malleus & No. of Cases & \% age & No. of cases & \%age \\
- & Intact & 6 & 24 & 4 & 16 \\
- & Necrosed & 19 & 76 & 21 & 84 \\
\hline Incus & Intact & 5 & 20 & 2 & 8 \\
$-\quad$ Necrosed & 20 & 80 & 23 & 80 \\
\hline Stapes & 11 & 44 & 20 & 20 \\
$-\quad$ Intact & 4 & 16 & 5 & \\
$-\quad$ Necrosed & 10 & 40 & & \\
\multicolumn{2}{|}{$\begin{array}{l}\text { Superstructure) } \\
-\quad \text { Not visualized }\end{array}$} & & & \\
\hline
\end{tabular}

\section{[II] STATUS OF SEMICIRCULAR CANAL, FACIAL CANAL AND LATERAL}

CORTICAL WALL:

Lateral semicircular canal erosion was depicted in one (4\%) case on CT and the same was confirmed peroperatively.

Facial nerve canal appeared eroded in 4(16\%) cases in tympanic segment on CT but was confirmed in $3(12 \%)$ cases peroperatively. Erosion of the vertical segment in $2(8 \%)$ cases seen peroperatively was not reported preoperatively on CT.

Lateral cortical wall appeared eroded in $2(8 \%)$ cases on CT and the same was confirmed peroperatively. (Table 9) 
TABLE9. STATUS OF SEMICIRCULAR CANAL, FACIAL CANAL AND LATERAL CORTICAL WALL

\begin{tabular}{|l|c|c|c|c|}
\hline \multirow{2}{*}{} & \multicolumn{2}{|c|}{ CT findings } & \multicolumn{2}{c|}{ Operative findings } \\
\cline { 2 - 5 } & $\begin{array}{c}\text { No. of } \\
\text { Cases }\end{array}$ & \% age & No. of cases & $96 \%$ \\
\hline LSCS Intact & 24 & $96 \%$ & 24 & $4 \%$ \\
\hline Eroded & 1 & $4 \%$ & 20 & $80 \%$ \\
\hline Facial Canal Intact & 21 & $84 \%$ & 5 & $20 \%$ \\
\hline Eroded & 4 & $16 \%$ & 23 & $92 \%$ \\
\hline Lateral cortical wall Intact & 23 & $92 \%$ & 2 & $8 \%$ \\
\hline Eroded & 2 & $8 \%$ & & \\
\hline
\end{tabular}

- Carotid canal wall was found intact in all cases both preoperatively on HRCT and peroperatively.

- Jugular canal wall was found intact in all cases both preoperatively on HRCT and peroperatively.

- In two cases intracranial complication in form of cerebellar and temporal lobe abscess was seen.

TABLE10. STATISTICAL ANALYSIS

\begin{tabular}{|l|c|c|c|c|c|}
\hline & Sen & Spe. (\%) & PPV (\%) & NPV (\%) & Accuracy (\%) \\
\hline DPE & 100 & 91.3 & 50 & 100 & 92 \\
\hline SPE & 100 & 100 & 100 & 100 & 100 \\
\hline STM & 100 & 100 & 100 & 100 & 100 \\
\hline CHOLESTEATOMA & 83.3 & 85.7 & 93.7 & 66.6 & 84 \\
\hline GRANULATION TISSUE & 85.7 & 83.3 & 66.7 & 93.7 & 84 \\
\hline MALLEUS EROSION & 90.4 & 100 & 100 & 66.6 & 92 \\
\hline INCUS EROSION & 87 & 100 & 100 & 40 & 92 \\
\hline FNCE & 75 & 95.2 & 95 & 95.2 & 100 \\
\hline LSCCE & 100 & 100 & 100 & 100 & 100 \\
\hline LCWD & 100 & 100 & 100 & 100 & 100 \\
\hline JCWE & 100 & 100 & 100 & 100 & \\
\hline CCWE & 100 & 100 & 100 & 100 & \\
\hline
\end{tabular}

\section{Discussion:}

The present study was conducted in the department of Otorhinolaryngology, IGMC, Shimla in which 25 cases of unsafe chronic suppurative otitis media were studied clinically and radiologically and subsequently subjected to surgery. The peroperative findings were correlated with that of preoperative HRCT findings.

Age: The cases included in the present study were in the age group varying from $2^{\text {nd }}$ to $5^{\text {th }}$ decade. Maximum number of patients was in the age group of 21-30 years, i.e. $13(52 \%)$ cases. Mean age group of the patients in the study was 26.76 years.

Sex: A female preponderance was seen in the present study with 14 females and 11 males. Female to male ratio being 1.27:1.Similar female preponderance was seen by others. [9, 10]

Dural plate and Sinus Plate: Dural plate was found to be intact in $21(84 \%)$ cases and erosion was present in 4 $(16 \%)$ cases on CT. Peroperatively dural plate was found to be intact in $23(92 \%)$ cases and eroded in $2(8 \%)$ cases. Jackler et al [6] detected all their cases but also had eight false positive cases. Mafee et al [11] missed 3 out of 8 cases. O'Reilly [12] commented that it is not possible to demonstrate reliably a dehiscence in the tegmen on axial scan alone but even using coronal cuts they found the effect of partial averaging could give the false impression of a defect. Sinus plate was observed to be intact in $22(88 \%)$ cases and eroded in $3(12 \%)$ cases on CT. Similar findings were confirmed peroperatively.

Mastoid cavity: Mastoids are almost universally involved in CSOM. CT was able to provide excellent views of the mastoid air cells, antrum and aditus ad antrum in either coronal or axial planes. The most common finding was of hypopneumatisation, which was present in $96 \%$ cases. Findings are consistent with others. [6].Seetana Ragavoodoo et al [13] found poorly pneumatised mastoid in 96\% cases and pneumatised mastoid in only $4 \%$ cases.

Soft tissue mass: In all 25 cases, soft tissue density mass was depicted by HRCT and was confirmed in all 25 cases peroperatively i.e. $100 \%$. This finding is in agreement with that of Reilly et al[12] and Shaffer et al.[14] 
However we could not distinguish cholesteatoma from other soft tissue disease. Walshe et al [15] in their study could not distinguish between mucosal disease and cholesteatoma. Cholesteatoma characteristically causes bone erosion and when this feature was present in association with a soft tissue mass on CT both Jackler et al[6] and O'Donoghue et al [9] found cholesteatoma to be present in $80 \%$ of cases explored. Using the same criteria, we detected 15 out of 18 cases of cholesteatoma.

Ossicles: Malleus on CT appeared to be intact in $6(24 \%)$ cases, but it was intact in $4(16 \%)$ cases peroperatively. Incus on CT appeared to be intact in 5(20\%) cases, but was found to be intact in $2(8 \%)$ cases peroperatively. On CT stapes appeared to be intact in 11(44\%) cases, eroded in $4(16 \%)$ cases and not visualized in $10(40 \%)$ Cases that were not visualized on CT, all were found to be intact peroperatively. The Incus was the most frequently eroded ossicle followed by the malleus and the stapes. This is consistent with the findings of Chee et al.[16] The malleus was the ossicle whose presence was predicted with greatest accuracy. This finding is consistent with O'Donoghue. [17] . On CT stapes appeared to be intact in 11(44\%) cases, eroded in 4(16\%) cases and not visualized in 10(40\%). On operative findings stapes was intact in 20 cases and eroded in 5 cases. Cases that were not visualized on CT, all were found to be intact peroperatively. The stapes was not consistently visualized by $\mathrm{CT}$, but when seen usually appeared as a structure of soft tissue density in the oval window niche. For this reason it was not possible to distinguish between the destruction of the stapes and its mere envelopment by soft tissue, findings are consistent with the findings of Jackler et al. [6]

Facial nerve canal: Facial nerve canal in its tympanic segment was intact in 21 cases (84\%), in 4 cases $(16 \%)$ it appeared eroded on CT. The latter findings were confirmed peroperatively in three cases $(3 / 4,75 \%)$. Vertical part of the facial nerve appeared intact in all cases on CT but was eroded in two cases peroperatively. In our study the tympanic segment of the facial nerve was the most susceptible to erosion. The findings are consistent with the observation of others $(6,12,16)$. Our detection rate for facial canal dehiscence is comparable to others.[11,12] O'Donoghue et al [9] appeared to have detected all 9 cases of facial canal dehiscence but also had 6 false positives. Eray Tuccar et al (18) carried out a study on formalin - preserved cadavers \& concluded that adequate information of the facial nerve anatomy could be obtained from standard HRCT scans

Semicircular canals: Lateral semicircular canal was eroded in one case on CT and it was confirmed peroperatively. A higher false positive rate was reported by others. [6,16] Anterior and posterior semicircular canals were intact on both CT and operatively. Findings are consistent with Silver et al [19], according to whom patients with vertigo and chronic middle ear disease may have a cholesteatoma with a fistula between the middle and inner ear and the fistula usually involves the Lateral semicircular canal. Vanclooster et al [20] also reported Lateral semicircular canal as the single most common location for the labyrinthine fistulas, because of its anatomic position in the antrum.

Lateral cortical wall: Lateral cortical wall was intact in 23(92\%) cases and was eroded in 2(8\%) cases. Same findings were confirmed peroperatively.

Carotid canal and jugular canal: There was no erosion of the bony wall separating carotid and jugular canal from middle ear on CT. Same findings were confirmed peroperatively. In two cases intracranial complication, in the form of cerebellar and temporal lobe abscess was seen.

\section{Conclusion:}

HRCT scans of the temporal bone have significantly enhanced the preoperative evaluation of unsafe CSOM. This study has shown that CT imaging for CSOM accurately depicts of soft tissue mass. It also effectively depicts the integrity or erosion of dural plate, sinus plate, lateral semicircular canal and lateral cortical wall. The ear ossicles malleus and incus are well depicted in the study. However, we could not effectively depict the integrity or erosion of facial nerve canal and more so the status of stapes.

It is concluded that computed tomography despite of its pitfalls such as more radiation exposure and higher cost delineates the location and extent of the disease, and provides information on anatomical variations and complications. It serves as a road map to assist the surgeon during surgery.

\section{References:}

[1]. Gregg JB, SteeleJP, Holzhueter A. Roentgenographic evaluation of temporal bones from South Dakota Indian burials. Am J Physical Anthropology. 1965; 23:51-62.

[2]. Mafee MF,Kumar A, Yannis DA, Valvassori GE, Applebaum EL. CT of the middle ear in the evaluation of cholesteatomas and other soft tissue masses: Comparison with Pluridirectional tomography. Radiology. 1983; 148:465-72.

[3]. Hughes GB. Cholesteatoma and the middle ear cleft: A review of pathogenesis. Am J Otol. 1979; 1:109-14.

[4]. Valvassori GE, Potter GD, Hanafee WN, Carter BL, Buckingham RA.Radiology of the ear, nose and throat. Philadelphia: WB Saunders; 1984 p. 222-8

[5]. Virapongse C, Rothman SG, Kier EL. Computed tomographic anatomy of the temporal bone. AJNR. 1982; 3:379-89. 
[6]. Jackler RK, Dillon WP, Schindler RA. Computed tomography in suppurative ear disease: a correlation of surgical and radiographic findings. Laryngoscope. 1984. 94:746-752.

[7]. Banerjee A, Flood LM, Yates P, Clifford K. Computed tomography in suppurative ear disease: does it influence management laryngol Otol. 2003; 117(6):454-8.

[8]. Briggs RD, GadreA. Differential diagnosis of temporal bone and skull base lesion. Quinn FB,Ryan MW eds. Grand Rounds Presentations,UTMB,Deptt. Of Otolaryngology,2001.

[9]. O'Donoghue GM ,Bates GJ, Anslow P, Rothera MP. The predictive value of high resolution computerized tomography in chronic suppurative ear disease.Clin otolaryngol. 1987; 12:89-96.

[10]. Bates GJEM, O’Donoghue GM, Anslow P, Houlding T. Can CT detect Labyrinthine Fistulae Preoperatively? Acta Otolaryngol (Stockh). 1988; 106:40-45.

[11]. Mafee MF, Levin BC, Applebaum EL, Campos M, James CF. Cholesteatoma of the middle ear and mastoid. A comparison of CT scan and operative findings. OCNA 1988; 21(2):265-293.

12. O'Reilly BJ, Chevratton EB, Wylie I, Thakkar C, Butler P, Sathanathan N, Morrison G, Kenyon GS. The Value of CT scanning in chronic Suppurative otitis media. J Laryngol Otol. 1991; 105:990-994. [PubMed]

[13]. Ragavoodoo S, Agarwal MK, Srivasatava A. A comparative study between preoperative CT scan findings and operative findings in cholesteatoma of the middle ear cleft. Indian. Journal of Otolaryngology and Head and Neck Surgery,S pecial issue-II,2005.

[14]. Shaffer Ka Haughton VM, Wilson CR. High Resolution Computed Tomography of the Temporal Bone. Radiology. 1980; 134:409-14.

[15]. Walshe P, McConn Walsh R, Brennan P, Walsh M. The role of computerized tomography in the preoperative assessment of chronic suppurative otitis media. Clin Otolaryngol Allied Sci. 2002 Apr; 27(2):95-7.

[16]. Chee NWC, Tan TY. The Value of Pre-operative High Resolution CT Scans in Cholesteatoma Surgery. Singapore Med J. 2001: 42(2) : $155-159$.

[17]. O'Donoghue GM. Imaging the temporal bone (Editorial).Clin Otolaryngol. 1987; 12:157-160.

[18]. Tuccar E, Tekdemir I, Aslan A,Elhan A,Deda H. Radiological anatomy of the intratemporal course of facial nerve. Clin Anat 2000; 13:83-87

[19]. Silver AJ, Janecka I, Wazen J,Hilal SK, Rutledge. Complicated cholesteatomas: Ct findings in inner ear complications of middle ear cholesteatomas. Radiology. 1987. Jul; 164:47-51.

[20]. Vanclooster C, Debruyne F, Vantrappen G, Desllovere C, Leenstra L. Labyrinthine Fistulas in Cholesteatoma.. Indian Journal of Otology. 1997; 3:3-6.

Figure1: (A) Temporal lobe abscess

(B) Cerebellar abscess

(C) Dural plate erosion

(D) Facial nerve canal erosion

Figure2: (A) Ice cone appearance of Malleus \& incus

(B) Lateral cortical wall erosion

(C) Lateral semicircular canal erosion

(D) Sinus plate erosion

Figure3: Soft tissue mass in epitympanum with intact scutum 